\title{
Thyroid Hormone Receptor Gene
}

National Cancer Institute

\section{Source}

National Cancer Institute. Thyroid Hormone Receptor Gene. NCI Thesaurus. Code C18562.

Thyroid Hormone Receptor Genes (Nuclear Receptor Family), c-erbA alpha and c-erbA beta, encode two isoforms each of c-erbA proteins (Thyroid Hormone Receptor) that specifically bind thyroid hormones and, thereby activated, regulate target gene transcription. ( $\mathrm{NCl})$ 